\title{
Impact of Coastal Erosion and Sedimentation along the Northern Coast of Sinai Peninsula, Case Study: AL-ARISH Harbor Coast
}

\author{
M. I. Balah ${ }^{1}$, I. Elshinnawy ${ }^{2}$, E. R. Tolba ${ }^{3}$ and M. Youness ${ }^{3}$
}

\begin{abstract}
Coastal activities during the past five decades have resulted in considerable shoreline change along the northern coast of Sinai Peninsula. In the east of El Arish Harbor, the shoreline is continuously retreating. Previous activities to mitigate the erosion have not succeeded. For example, the groin field in the east of the El Arish Harbor has transferred the problem to the neighboring beaches farther downcoast. The shoreline change at El Arish Harbor was modeled using the coastal evolution model LITLINE. Having understood the coastal processes driving the shoreline change at this site, appropriate remedial measures were proposed to mitigate the problem.
\end{abstract}

Keywords: El Arish Harbor, Erosion, Accretion, LITLINE, LITDRIFT, LITPACK, Shoreline Change Modeling, Sinai Coast.

\section{INTRODUCTION}

(1) The coast represents one of the most important, if not one of the most complex, linear features on Earth, marking the interface between land, sea and the overlying atmosphere, and between different levels of government, jurisdictional responsibility, or resource management. So in studying any issue concerned with this coastline evaluation, it is important to surround all the subjects that affect the judgment of the study area, to have the right decision.

According to [10] beach or shore is the zone of unconsolidated material that extends from the mean low water line to the place where there is a marked change in material or physiographic form, or to the line of permanent vegetation (the effective limit of storm waves and storm surge), i.e. to the coastline. The beach or shore can be divided in the foreshore and the backshore.

(2) In order for one shore to accrete, often some other shore must erode. Erosion is a natural response to the water and wind processes at the shore, but erosion is only a problem when human development is at risk. Sometimes, man-made alterations to the littoral system, including modifications to sediment sources or sinks, may contribute to the eroded condition.

\footnotetext{
${ }^{I}$ Civil Engineering Department, Faculty of Engineering, Suez Canal University, Ismailia, Egypt

2 Coastal Research Institute (CORI), 15 El-Pharaana St., ElShallalat, 21514 Alexandria, Egypt

${ }^{3}$ Civil Engineering Department, Faculty of Engineering, Port Said University, Port Said, Egypt

Email:Youness_1928@yahoo.com
}

There are no absolute rules, nor absolute solutions to the problem of coastal erosion given the dynamic and the diverse character of the shoreline. No single set of regulations, or single land use management philosophy, is appropriate for all coastal situations or settings. The diversity of the coasts requires consideration of a variety of solutions when addressing problems in a particular area. [1]

(3) A decrease in the supply of sediments to a shoreline, due to the regulation of rivers, which previously supplied material to the shoreline, is a very common cause of coastal erosion. The river regulation works can be the construction of dams for power production and irrigation purposes, or the deepening of navigation channels and sand mining, but all of them cause less supply of sediment to the shoreline. Perhaps the best-known example of this is the trapping of the sediments of the Nile River by the construction of the High Aswan Dam in the 1960's. [10]

When there is a decrease in the net transport rate between incoming and outgoing transport in a compartment, sediment accumulation takes place on the beach resulting in accretion. The magnitude of accretion will equal the difference between volumes of the transported sediments to-and-fro the compartment. This is where beach acts as an accumulation spot for the transported sediment load.

The main objectives of this study were to: (1) identify the predominant coastal processes affecting the erosion and sedimentation along the Sinai northern coastline; (2) investigate the impact of harbor on the shoreline change; and (3) propose protective measures for alleviating the erosion problems. 


\section{Study Area}

The study area lies between longitudes $32^{\circ} 20^{\circ} \mathrm{E}$ and $34^{\circ} 13^{`} \mathrm{E}$ and latitudes $31^{\circ} 16^{`} \mathrm{~N}$ and $31^{\circ} 19^{\circ} 6 \mathrm{~N}$ on the northern coast of Egypt. The stretch of interest covers more than $208 \mathrm{~km}$ of the coastline from East of PortSaid extending as far as to the northern border of Sinai see figure 1. The northern coast of Sinai is like plain and lacks vegetation.

Sinai is a triangular peninsula occupying the northeastern corner of Egypt. It represents a geographic transition zone between Asia and Africa, bounded on the west by the Gulf of Suez and the Suez Canal, on the east by the Gulf of Aqaba and the EgyptianPalestinian border and on the north by the Mediterranean Sea.

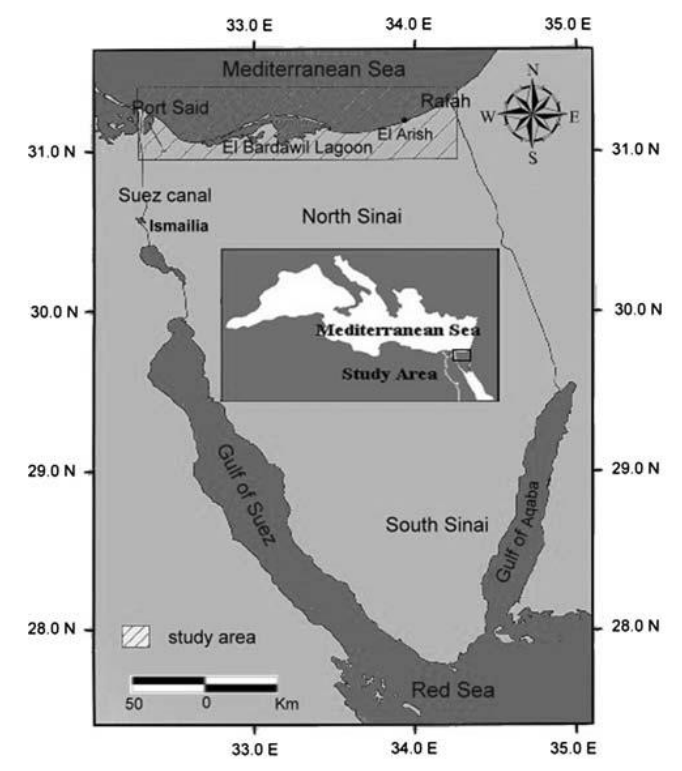

Figure 1: Location map for the study area

Two protruding headlands at Port Said and the Bardawil bulge coast interrupt the generally smooth coastline. These headlands are separated by two large embayments. The coastline at these embayments comprises sand dunes and lowlands made of saltpans known as "sabkha" deposits [6]. From Port Said to the west of Bardawil lagoon the coastline is characterized by conspicuous type of landforms namely; sandy shore, coastal plain marginal lagoons, Nile flood plain, sand dune belt and sabkha deposits [3].

To the east of the lagoon the shoreline mainly comprises sandy spit formations, heading to the east, located at the eastern end of the barrier of Bardawil lagoon. The lagoon is separated from the Mediterranean by a $500 \mathrm{~m}$ wide and $80 \mathrm{~km}$ long, curved, narrow sand barrier. It is connected to the open Mediterranean Sea by three inlets, two artificial and one natural [6].

According to a study performed by [9], the longshore sand transport from the Bardawil Lagoon is about 500 $000 \mathrm{~m}^{3} / \mathrm{yr}$ and gradually decreases to the north with the northerly bend in coastline. This divergence in the littoral drift of sand results in the build-up of extensive dune fields along the coasts of the delta, Sinai, and Palestine. The estimation was based on aerial photos of trapped sand on the western side of the Bardawil lagoon inlet jetties [9].

El-Arish city coastline have an amazing features, like the palm trees coast, many recreational villages, and the sand dunes fields, also have some important infrastructure like El-Arish Harbor and El-Arish Power Plant.

One example of infrastructure projects that have intensified the coastal erosion at the Sinai northern coast is El Arish Harbor. Sand mining from the beach as a source of construction material for development activities has produced a sand deficit along many coastal stretches causing accelerated erosion of beaches and nearby cliffs/dunes [13].

The northern part of Sinai is mainly affected by northwesterly winds coming from the Mediterranean Sea. The monthly wind speed recorded at the meteorological stations in El Arish, Port Said, and Ismailia ranges from 2.6 to $11.3 \mathrm{~m} / \mathrm{s}$. The northern part of Sinai is subject to sandstorms, called El-Khamasin, which blow from the south and the southwest intermittently over a period of 50 days during February and March [12].

\section{One-line Theory}

The seasonal variations in wave climate cause sediment to be transported crossshore leading to changes in bottom profile. However, unless a very destructive storm happens, the change in the profile returns to its pre-storm shape in a short time such that the shape of the profile remains constant over a long period [8].

Within the light of the basic assumption of an unchanged beach profile considered in long term scale, the beach profile, keeping stable, moves parallel to itself either onshore (causing erosion) or offshore (leading accretion), up to a depth, so-called depth of closure, the offshore side of which is free from sediment motion or has so little sand movement that can be neglected.

All the contours extend parallel to the shoreline and move the same distance, since the profile is constant in shape. Therefore one-line modeling uses a single line as the name implies and practically the shoreline is taken as the one dimensional contour line to represent the complete beach movement [11].

Pelnard-Considere (1956) was the first to introduce one-line theory. There are many researchers who have studied on one-line theory after that time and the recent numerical models based on one-line theory are given in [11] which are the ones developed by Perlin and Dean (1983), GENESIS by Hanson and Kraus (1989) and ONELINE by Kamphuis (1993), Dabees and Kamphuis (1998), and Dabees (2000).

In figure 2 , it is seen that the profile is constant down to the depth of closure and the initial profile, as a block, moves seaward or landward, where $D_{B}$ is the berm height and $\mathrm{D}_{\mathrm{C}}$ is the depth of closure. If the longshore variations of shoreline dominate the short term fluctuations of shape of beach profile, one-line 
modeling is very well applicable and gives reasonable results in the vicinity of coastal structures [8].

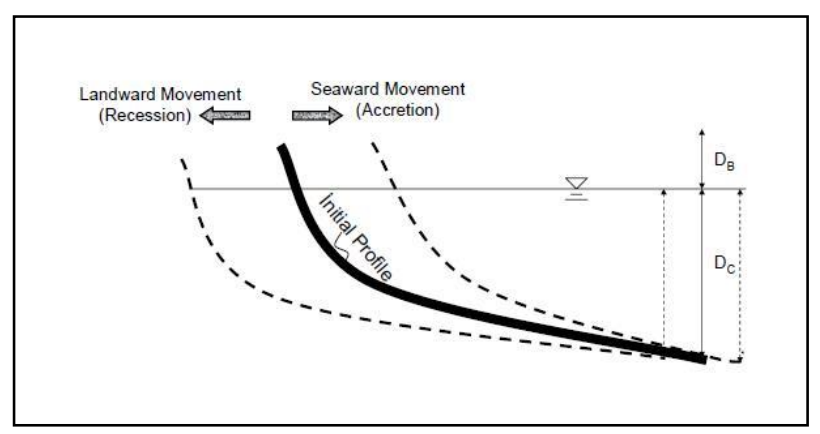

Figure 2: Bottom profile and change of shoreline.

\section{Shoreline Response Modeling}

LITPACK program is an integrated modeling system for littoral processes and coastline kinetics, developed by DHI, Water and Environment; it is a software package for simulating non-cohesive sediment transport in waves and currents, littoral drift, coastline evolution and profile development along quasi-uniform beaches.

The main modules of the LITPACK are as the followings: Non-cohesive sediment transport (LIST); Long-shore current and littoral drift (LITDRIFT); Coastline evolution (LITLINE); Cross-shore profile evolution (LITPROF) and Sedimentation in trenches LITTREN), two modules only will be used LITDRIFT and LITLINE.

LITDRIFT calculates the net/gross littoral transport over a specific design period. Important factors, such as linking of the water level and the profile to the incident sea state, are included.

Based upon the results from LITDRIFT, LITLINE simulates the coastal response to gradients in the longshore sediment transport capacity resulting from natural features and a wide variety of coastal structures.

LITLINE calculates the coastline evolution by solving a continuity equation for the sediment in the littoral zone. The influence of structures, sources and sinks is included. With jetties and breakwaters, the influence of diffraction on the wave climate is included.

LITLINE calculates the coastline position based on input of the wave climate as a timeseries. The model is, with minor modifications, based on a one-line theory, in which the cross-shore profile is assumed to remain unchanged during erosion/accretion. Thus, the coastal morphology is solely described by the coastline position (cross-shore direction) and the coastal profile at a given long-shore position.

Through successive calls to LITDRIFT, the associated program LINTABL calculates and tabulates transport rates as functions of the water level, the surface slope due to regional currents, wave period, height and direction compared to the coastline normal.
The main equation in LITLINE is the continuity equation for sediment volumes:

$$
\frac{\partial y_{c}(x)}{\partial t}=-\frac{1}{h_{a c t}(x)} \frac{\partial Q(x)}{\partial x}
$$

In which $y_{c}(x)$ is the coastline position "distance from the baseline to the coastline", $\mathrm{t}$ is time, $Q(x)$ is the longshore transport rates, and $x$ is the long-shore position.

The total height of the active profile $h_{a c t}(x)$ "height of the active cross-shore profile" consists of three contributions:

1. The active depth relative to mean water level. "DC"

2. The height of the beach above mean water level which moves forth and back with the coastline position. " $\mathrm{D}_{\mathrm{B}}$ "

3. And finally possible "dunes", which may erode if the coastline reaches their position during erosive states, but will not accrete again.

The evolution in time is determined by solving equation (1), using an implicit Crank-Nicholson scheme. [2]

\section{Data collection}

\subsection{Bathymetry}

In LITPACK it is assumed that the coastline is quasiuniform, i.e. the bottom contours are almost parallel to the coast. This way the hydrodynamics (longshore current and wave variation across the profile) can be calculated in one dimension (profile normal to the depth contours) as if the current profile is fully developed and no disturbances in the bathymetry are present in the longshore direction.

Generally, seafloor contours of the nearshore study zone are nearly parallel to the coastline, with no dominant seabed features. Beach-nearshore slopes generally have two main slope gradients. An inner, relatively steep slope (1:50) extends offshore, followed by an outer gentle slope of 1:600. Generally, the inner slope part terminated at about 8-m water depth along the study coastline. The shoreline of the study area is typically a straight, smooth sandy beach oriented more or less in a west-east trend. [7]

\subsection{Sediment Properties}

The sediment properties must be defined for each grid point in the crossshore profile. To include the variation of the sediment size (usually the sediment size will become finer by increasing depth). LITPACK calculates the sediment transport capacity (i.e. assumes that there is an unlimited source of sediment supply). If some parts of the seabed are hard rock (which not found in this case study), the conclusions of the simulation results must be modified accordingly, or put a revetment instead of the coastline. 
The beach and littoral sediments of the north Sinai are derived from eroded beaches and the inner shelf of the Nile delta by eastward littoral currents and currents generated by the east Mediterranean gyre. Medium and fine sand occur in the beach area $(\mathrm{Mz}=0.24$ to 0.48 $\mathrm{mm})$, whereas very fine sand and coarse silt cover the nearshore zone ( $\mathrm{Mz}=0.06$ to $0.13 \mathrm{~mm})$. [7]

It can be seen that the accretion west of El Bardawil inlet1, El Bardawil inlet2 and west of El Arish Harbour is characterised by dominance of moderately sorted medium-grained sands. The average mean grain size $(\mathrm{Mz})$ of beach sands in these accretion sectors are 0.25 , 0.30 and $0.32 \mathrm{~mm}$, respectively. [12]

\subsection{Tidal data}

The variation of the water level must be known as the position of the water level influences the computations of hydrodynamics and sediment transport.

The coastline of the Sinai is of typical microtidal semi-diurnal nature. Recorded daily water-level variations measured from the mean sea level in the study area reveal a mean high-water level and a mean low-water level of 20.22 and $-11.01 \mathrm{~cm}$, respectively, with a tidal range of $31.23 \mathrm{~cm}$. [7]

\subsection{Wave climate}

In LITDRIFT and LITLINE the main input parameters for the hydraulic computations are the wave properties: wave height, wave angle and wave period for a given (outer) depth in the profile (preferably the first grid point). From this position the program will shoal and refract the waves across the profile onto the coast and calculate the resulting longshore current across the profile. The variation across the profile of the wave height, wave angle and longshore current velocity are given as output.

A wave rose averaging the 16-month period is depicted in Figure 3. and table 1. Data examined in this study show low-swell waves prevailing during spring and summer, with wave heights rarely exceeding 1-1.5 $\mathrm{m}$ for waves blown from the WNW and rarely from the NE. Winter waves are much higher than summer waves, fluctuating between stormy and calm intervals and coming from the $\mathrm{N}, \mathrm{NNW}$ and NW sectors. These are the predominant cause of morphological changes (Figure 3). In order to analyze beach changes, the relationships between incoming waves and shoreline orientation are incorporated. Applying the guidelines given in [10], the relationship between wave climate and the present shoreline orientation, $80^{\circ}$ to the north, provides an oblique wave exposure presented schematically in the Figure. Two main wave component groups are responsible for generating easterly and westerly sediment transport (see the two arches in Figure). Accordingly, the predominant wave directions (NNW, NW and WNW, totaling 69\%) are responsible for the generation of longshore currents towards the east due to northwest winds. This is in addition to small percentages from the $\mathrm{N}$, NNE and NE sectors which generate a reverse longshore current towards the west, particularly during March and April, totaling 29\%. The remaining insignificant frequency $(2 \%)$ represents calm conditions, generally for waves approaching from land, i.e., from SW and SE quadrants. On the whole, the average wave height and period are $0.5 \mathrm{~m}$ and $6.3 \mathrm{~s}$, respectively. Generally, the recorded average wave direction-height distribution revealed that the frequency distribution of wave height between 0.5 and $1.0 \mathrm{~m}$ is more dominant than others between $1-$ and 2$\mathrm{m}$ heights. [7]

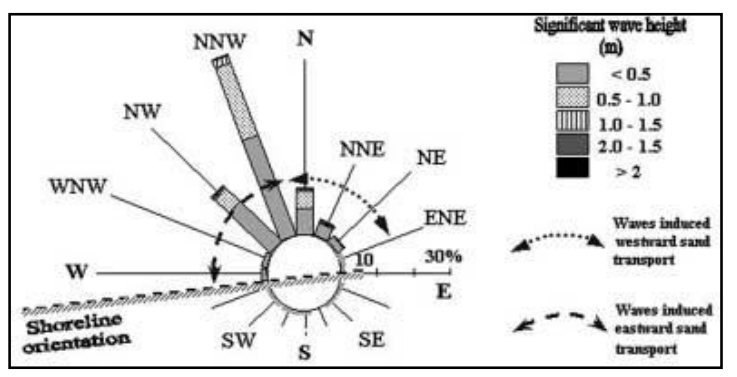

Figure 3: Wave rose along with the average orientation of the present coast and the two wave exposures denoted by arches [7].

\subsection{Historical Coastline}

LITLINE needs some calibration data. This could be maps of historical coastline evolution, aerial photographs of the coastline from different years or knowledge of erosion/deposition rates during a season with known wave conditions.

Using digitizing of satellite images, two shorelines was surveyed one on (6-6-2006) and the other one was taken in (1-12-2007).

The contour lines surveyed by the Egyptian Shore Protection Authorities SPA in 2005 and in 2009 with the of the sea side to the depth of $(-10.00 \mathrm{~m})$ is available.

\section{The Model}

A groin field was built east AL-ARISH harbor to prevent the shoreline retreat that threat the beautiful palm beaches. Two aerial images were taken to the site with two different dates, one was taken in (6-6-2006) and the other one was taken in (1-12-2007). The images were obtained from Google Earth Plus, see figure 4.

Using the (drawing path) option in the Google Earth program from the ruler tool, the shoreline of the site was drawn for the two different dates. Then the shoreline was digitizing using the Raster to Vector program. The tip of the secondary breakwater of the harbor was taken as a control point. 
Table 1. The direction, height, and duration of the previous wave rose [7].

\begin{tabular}{|c|c|c|}
\hline $\begin{array}{c}\text { Direction } \\
\text { (Degree) }\end{array}$ & Height (m) & $\begin{array}{c}\text { Duration } \\
\text { (Pct./Year) \% }\end{array}$ \\
\hline 270 & 0.25 & 1 \\
\hline 292.5 & 0.75 & 1.8 \\
\hline \multirow{3}{*}{315} & 0.25 & 13.5 \\
\cline { 2 - 3 } & 0.75 & 5.4 \\
\cline { 2 - 3 } & 2.1 & 0.9 \\
\hline \multirow{3}{*}{337.5} & 0.25 & 26.2 \\
\cline { 2 - 3 } & 0.75 & 18.9 \\
\cline { 2 - 3 } & 1.25 & 2.3 \\
\hline \multirow{3}{*}{0} & 0.25 & 9.4 \\
\cline { 2 - 3 } & 0.75 & 7.3 \\
\cline { 2 - 3 } & 2.1 & 1.4 \\
\hline \multirow{3}{*}{22.5} & 0.25 & 4.4 \\
\cline { 2 - 3 } & 2.1 & 2.2 \\
\hline \multirow{2}{*}{45} & 0.25 & 1.5 \\
\hline \multirow{2}{*}{67.5} & 2.1 & 2.8 \\
\hline
\end{tabular}

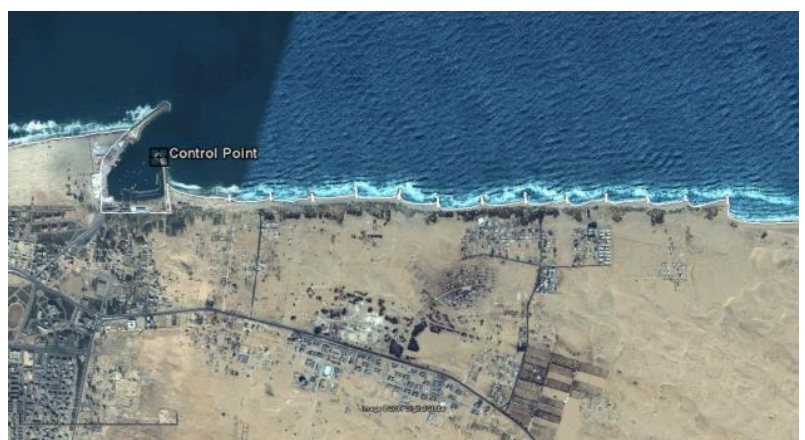

Figure 4.a. Aerial view of the site dated on (6-62006).

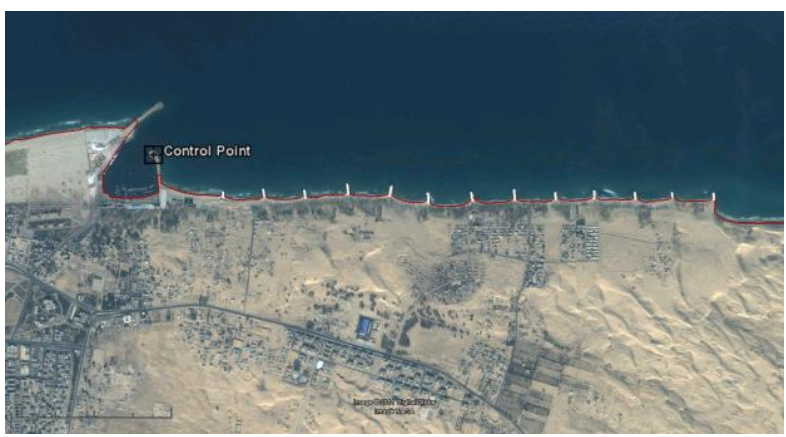

Figure 4.b. Aerial view of the site dated on (1-122007).
To choose the suitable data to complete the simulation with LITLINE: A LITDRIFT model was built for each relevant profile and corresponding wave climate. Some information of the profile sediment properties was used. Table 2 shows the different results from the LITDRIFT models.

Table 2. Different LITDRIFT model's results

\begin{tabular}{|c|c|c|c|}
\hline \multicolumn{3}{|c|}{ Sediment Properties } & \multirow[b]{2}{*}{$\begin{array}{c}\text { Net sediment } \\
\text { Transport } \\
\text { (m³/year) }\end{array}$} \\
\hline $\begin{array}{c}\left(\mathbf{M}_{\mathrm{z}}\right) \\
{[\mathrm{mm}]}\end{array}$ & $\begin{array}{c}\text { Roughness } \\
{[\mathrm{m}]}\end{array}$ & $\begin{array}{c}\text { Fall } \\
\text { velocity } \\
{[\mathbf{m} / \mathbf{s}]}\end{array}$ & \\
\hline 0.2 & 0.002 & 0.0235 & $0.1335 E+07$ \\
\hline 0.23 & 0.0023 & 0.03 & $0.5192 \mathrm{E}+06$ \\
\hline 0.3 & 0.003 & 0.0454 & $0.1536 \mathrm{E}+06$ \\
\hline 0.32 & 0.0032 & .05 & $0.1348 \mathrm{E}+06$ \\
\hline
\end{tabular}

The distribution of the long-shore transport along the coastal profile is shown in Figure 5.

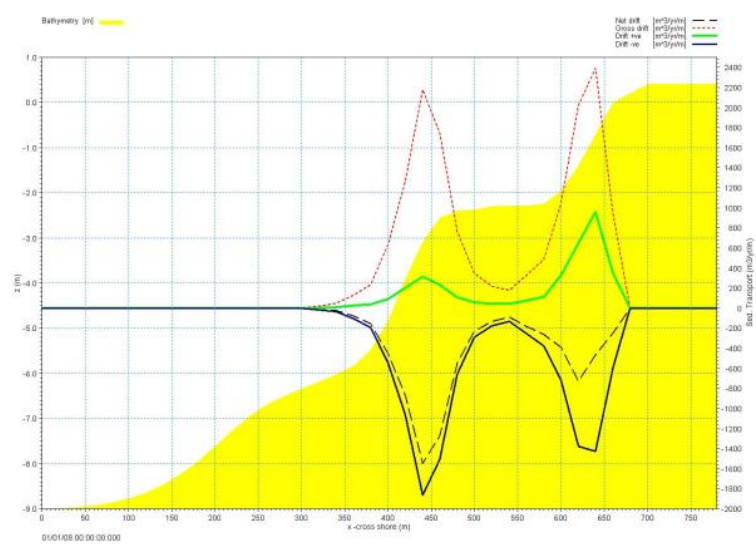

Figure 5: Cross-shore distributions of net- and gross long-shore transport along the profile.

The data chosen for the simulation was the Frihy wave rose with $0.3 \mathrm{~mm}$ (Mean grain diameter) for the sandy beach. The Net sediment Transport was 153600 $\mathrm{m}^{3} /$ year which close to $153000 \mathrm{~m}^{3} /$ year calculated by [5].

After digitizing the satellite images, a simulation for the groin field was performed for a 12-month interval between 06-06-2006 and 05-06-2007, by building a LITLINE model to simulate the shoreline evaluation using 127 cells to present the initial coastline creating a baseline with $5080 \mathrm{~m}$ long and $5813.9 \mathrm{~m}$ coastline stretch.

Many simulations were performed to calibrate and understand how the input parameters affected the simulation results. The calculated final shoreline can be seen in figure 6. Exporting results into graphs and animated images done by PLOT COMPOSER in MIKE Zero package. 


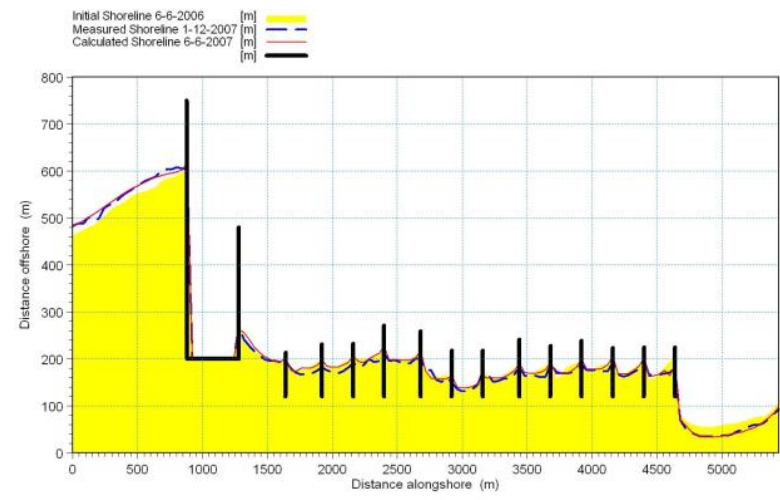

Figure 6: Simulated and measured final shorelines for the calibration of the model for the eastern groin field.

Table 3. Model settings and calibration and verification parameters

\begin{tabular}{|c|c|c|}
\hline Parameter & value & Units \\
\hline Total number of Cells & 127 & {$[-]$} \\
\hline Angle of Normal to Baseline & 343 & {$\left[{ }^{\circ}\right]$} \\
\hline Height of Active Beach & 0.4 & $\mathrm{~m}$ \\
\hline Active Depth & 3.0 & $\mathrm{~m}$ \\
\hline $\begin{array}{c}\text { Limiting Depth for Offshore } \\
\text { Contours }\end{array}$ & 9.0 & $\mathrm{~m}$ \\
\hline Maximum Active Length & 780.0 & $\mathrm{~m}$ \\
\hline Maximum Courant Number & 1 & {$[-]$} \\
\hline Crank-Nicolson Factor & 0.25 & {$[-]$} \\
\hline
\end{tabular}

The parameter values that generated the best agreement between the measured shoreline and the calculated final shoreline are presented in table 3. The mean absolute difference distance (called calibration / verification error in LITLINE) between the measured and calculated shoreline is $6.2 \mathrm{~m}$.

\subsection{Sensitivity testing for the model}

Sensitivity testing refers to the process of examining changes in the output of a model resulting from intentional changes in the input parameters. If large variations in the output from the model are caused by a small change in the input, calculated results will depend too greatly on the quality of the verification, which increases the uncertainty of the model predictions. If the model is too sensitive to small changes in input values, the range of possible predictions by the model will be too wide and it will not generate any useful information [5].

The sensitivity test was performed in a systematic manner, by applying a change to only one parameter at a time for each simulation run. The change was in $1 \%$ range (increasing or decreasing). Figure 7 , shows how the verification shoreline responds to the different changes in parameter values for Active Depth, grain size, maximum Courant Number, and Crank-Nicolson Factor. Table 4 shows the changes in simulation result for the different input parameters.

Table 4. Sensitivity testing for different parameters as well as a mean absolute difference distance between final verified shoreline and calculated sensitivity testing shorelines.

\begin{tabular}{|c|c|c|c|c|}
\hline Parameter & value & Units & $\begin{array}{c}\text { relative } \\
\text { change }\end{array}$ & $\begin{array}{c}\text { error } \\
(\mathbf{m})\end{array}$ \\
\hline Active Depth & 3.03 & $\mathrm{~m}$ & $+1 \%$ & 0.10 \\
\hline Grain size & 0.29 & $\mathrm{~mm}$ & $-3.3 \%$ & 0.17 \\
\hline
\end{tabular}

The model did not show much sensitivity against small changes in the input parameters implying that the verification simulation could be considered as rather reliable.

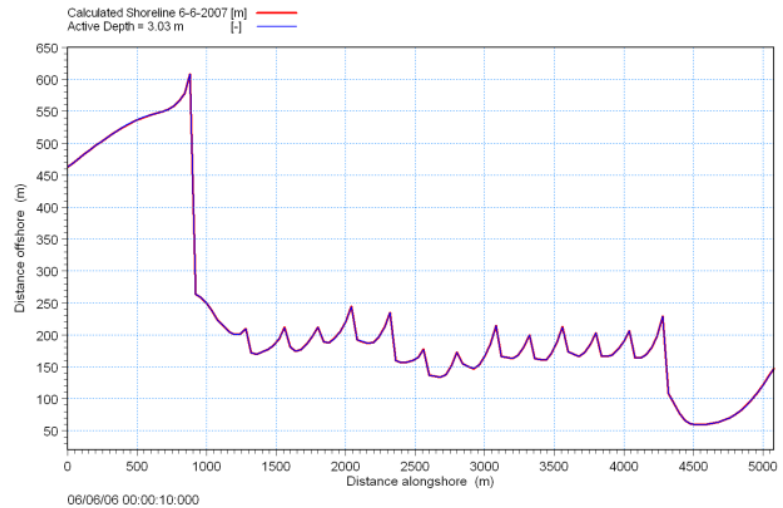

Figure 7.a. Results of sensitivity testing for the previous model with regard to change in active Depth.

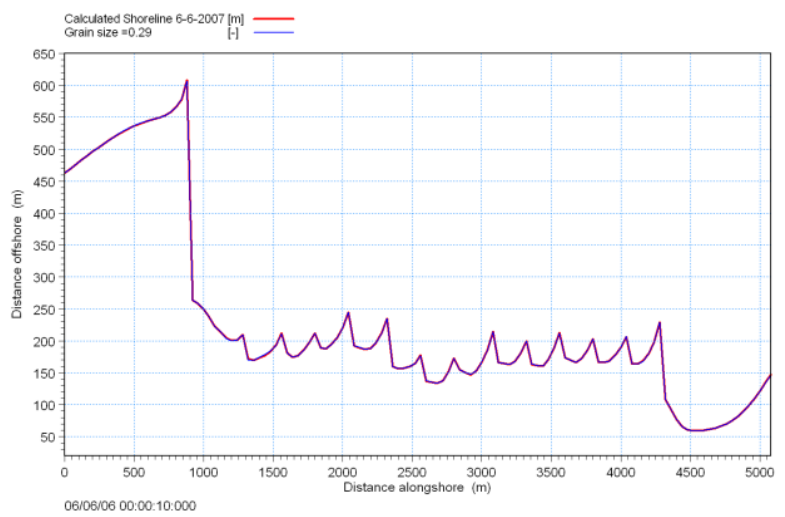

Figure 7.b. Results of sensitivity testing for the previous model with regard to change in grain size. 


\section{Remedial measures}

Blockage of longshore sediment transport by the long breakwater of the harbor destabilized the downcoast beach in the form of erosion. Sediment entrapment by the groin field east of the harbor has resulted in local protection against erosion downdrift of the El-Arish harbor. Nevertheless, it is evident that this method has substantially altered the natural longshore movement of sediment. The model simulation period was extended with 10 years to see the effect of the nourishment scenario described below. The simulations started during 2008 and utilize the shoreline from the same year as the initial shoreline.

\subsection{Do nothing (no action scenario)}

To examine the probable changes of the shoreline 10 years were added to the calibration simulation period and the model was run for a no-action scenario. As expected, the shoreline continues to accrete in the west and erode in the east (see figure 8). Immediately updrift of the breakwater the 2018 shoreline is likely to advance about $50 \mathrm{~m}$ as compared with 2008 shoreline. In the east of the harbor, at about $3400 \mathrm{~m}$ alongshore where most serious erosion occurs, the shoreline retreats more than $90 \mathrm{~m}$ if no mitigation measure is applied. This trend will result in loss of the Palm Beach which is a beautiful beach resort at the Sinai northern coast. For this reason, application of beach nourishment along this part of the beach is the almost proper solution.

According to the simulation the erosion trend in the area will continue and over $211^{\prime} 000 \mathrm{~m}^{3}$ of sand is lost from the beach during the run and about $70^{\prime} 000 \mathrm{~m}^{2}$ of land property will be lost. The no action solution in this case will be catastrophe, the state will loss more than 23 million dollar if no mitigation measure is applied.

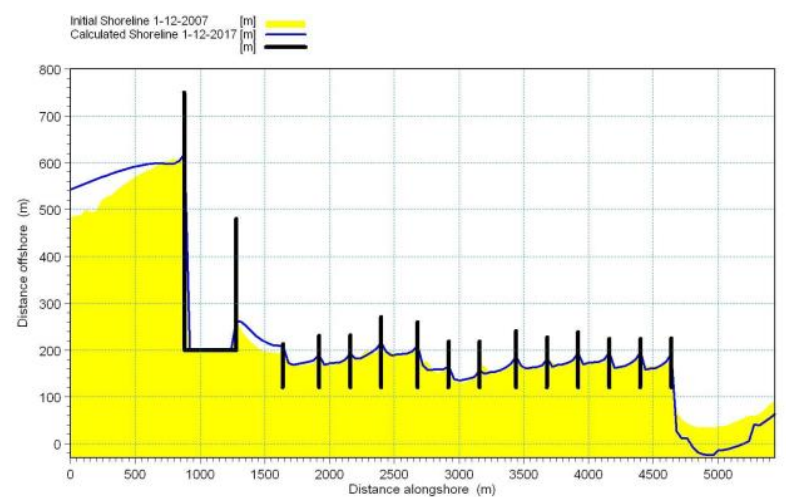

Figure 8: Result of a forecast simulation extending 10 years after the verification with no coastal measures implemented to the shoreline after the groin field.

\subsection{Beach nourishment}

A volume of $21^{\prime} 100 \mathrm{~m}^{3} /$ year of this sand is then placed back on the beach from the last groin to a distance of $1000 \mathrm{~m}$ alongshore to maintain the shoreline without erosion; it will cost the state 175 thousand dollar per year.

Creation of a feeder beach downdrift of the groin field is recommended. The unidirectional eastward sediment transport along the Sinai northern coast distributes the fill material farther downcoast. According to [1], feeder beaches can be applied in areas that are presently suffering deficit in the supply of littoral material and have unusually high loss rates, and also, in areas where the net longshore transport rate is predictable and the net longshore transport in one direction greatly exceeds the net longshore sediment transport in the other direction.

Beach nourishment is intended to widen the eroding beach and form an erosional buffer zone. Coastal erosion is an ongoing process and the nourished sand erodes away after sufficient amount of time has elapsed. The beach shall be renourished periodically such that the erosional buffer zone is rebuilt. In addition to protecting the shoreline from erosion, beach nourishment has recreational advantages as well and, therefore, best suits touristic beach resorts. [5]

\section{Conclusions}

1. The northern coast of the Sinai Peninsula has been subject to appreciable changes that have been intensified by human influence. Placement of the harbor at El Arish has obstructed the longshore sediment transport resulting in shoreline advance and retreat.

2. Using beach nourishment as a remedial measure will save more than 2 million dollar per year for the state.

3. The LITPACK model can be successfully applied for this case, calculating and forecasting orientation of coastal line changes due to erosion and sedimentation process.

\section{References}

[1] CEM, 2008,"Coastal Engineering Manual", Coastal and Hydraulics Laboratory (CHL), Engineer Research and Development Center (ERDC), Vicksburg, Mississippi.

[2] Danish Hydraulic Institute (DHI), "An integrated modeling system for littoral processes and coastline kinetics, short introduction and tutorial”, DHI Software, Copenhagen, 2003.

[3] Dewidar, K.M. and Frihy O. E. (2003). "Thematic Mapper Analysis to Identify Geomorphologic and Sediment Texture of El Tineh Plain, North-western Coast of Sinai, Egypt," International Journal of Remote Sensing, 24(11), 2377-2385.

[4] DHI Software (2008). LITPACK - An integrated modeling system for littoral processes and coastal kinetics - User Guide. Danish Hydraulic Institute.

[5] Emanuelsson, D. and Mirchi, A. (2007). "Impact of Coastal Erosion and Sedimentation along the Northern Coast of Sinai Peninsula," Report TVVR 07/5006, Water Resources Engineering, Lund University, Lund, Sweden.

[6] Frihy, O.E. and Lofty, M.F. (1997). "Shoreline Change and Beach-sand Sorting Along the Northern Sinai Coast of Egypt," Geo-Marine Letters, 17, 140-146. 
[7] Frihy, O.E., Badr, A.A., Selim, M.A., El Sayed, W.R., (2002). "Environmental Impacts of El Arish Power Plant on the Mediterranean Coast of Sinai, Egypt," Environmental Geology, 42, 604-611.

[8] HANSON, H., and KRAUS, N. C. (1989), GENESIS: Generalized Model for Simulating Shoreline Change, Report 1, Technical Reference, Technical Report CERC-89-19, Coastal Engineering Research Center, US Army Engineer Waterways Experiment Station, Vicksburg, MS.

[9] Inman, D.L. (2005). "Littoral cells," In: M. Schwartz, Editor, Encyclopedia of Coastal Science, Springer, Dordrecht, Netherlands, 594-599.

[10] K. Mangor, Shoreline management guidelines, Danish Hydraulic Institute, Copenhagen, 2004.

[11] Kamphuis, J.W., (2000), "Introduction to Coastal Engineering and Management", World Scientific, Singapore-New Jersey-London-Canada

[12] Mahmoud M. El Banna and Mohamed E. Hereher, 2008, "Detecting temporal shoreline changes and erosion/accretion rates, using remote sensing, and their associated sediment characteristics along the coast of North Sinai, Egypt", Environ Geol (2009) 58:14191427

[13] Rosen, D.S., 2002, "Long Term Remedial Measures of Sedimentological Impact due to Coastal Development on the South Eastern Mediterranean Coast", Littoral 2002, The Changing Coast, 321-331. 